\title{
Uitrustingevaluering: 'n kwantitatiewe benadering
}

\author{
Kmdt. W.J. Wagner* \\ Prof J.S. Wolvaardt
}

\section{INLEIDING}

Ten einde uitrusting, militêr of andersins, effektief te evalueer, is dit nodig om die eienskappe daarvan te meet, hetsy prakties of teoreties. Die bepaalde resultaat word dan in ' $n$ waardestelsel, soos 'n hiërargiese boom, geplaas en hieruit word die effektiwiteit van die uitrusting bepaal. As gevolg van tekortkominge wat in huidige metodes bestaan, het dit nodig geword om 'n nuwe metode te ontwikkel wat op die tekortkominge sal verbeter.

\section{SITUASIE}

Gestel 'n tenk, genaamd die Leeu MK 1, moet geëvalueer word ten einde sy effektiwiteit te bepaal. Die volgende metode word gevolg:

(a) Stel 'n hiërargiese boom op met die hoofeienskappe as oorgangsnodes en meetbare eienskappe as eindnodes (diagram 1).

(b) Ken gewigte aan eienskappe toe

(c) Definieer transformasies wat meetbare prestasies na breuke omskakel.

(d) Evalueer vervolgens die tenk, transformeer die bepaalde prestasies na breuke, vermenigvuldig die breuke met die gewigte en sommeer die resultate om 'n geweegde rekenkundige gemiddelde te verkry.
$\mathrm{Na}$ afloop van die evaluasie is resultate behaal soos vervat in tabel 1 . Soos gesien kan word presteer die Leeu MK 1 goed en kan, deur net die stelseleffektiwiteit in ag te neem, besluit word om die voertuig aan te koop.

\begin{tabular}{|c|c|c|c|}
\hline $\begin{array}{l}\text { Meetbare } \\
\text { Eienskap }\end{array}$ & $\begin{array}{c}\text { Breuk be- } \\
\text { haal }(P)\end{array}$ & Gewig (G) & $P \times G$ \\
\hline Snelheid & 0,9 & 0,4 & 0,36 \\
\hline Krag & 0,9 & 0,6 & 0,54 \\
\hline Akkuraatheid & 0,1 & 0,7 & 0,07 \\
\hline Reaksietyd & 0,1 & 0,3 & 0,03 \\
\hline $\begin{array}{l}\text { Penetrasie- } \\
\text { weerstand } \\
\text { Effek na }\end{array}$ & 0,7 &, 5 & 0,35 \\
\hline penetrasie & 0,6 & 0,5 & 0,3 \\
\hline
\end{tabular}

Stelseleffektiwiteit $=(0,36+0,54) \times 0,5+$

$$
\begin{aligned}
& (0,07+0,03) \times 0,3+ \\
& (0,35+0,3) \times 0,2
\end{aligned}
$$$$
=0,61
$$

As in besonderheid gekyk word, blyk dit egter dat die vuurkrag van die Leeu MK1 baie swak is, maar dat daarvoor opgemaak word deur die uitstekende mobiliteit en beskerming. Aangesien

\section{DIAGRAM 1. 'N BREË HIËRARGIESE BOOM VIR DIE EVALUERING VAN 'N PANTSERVEGVOERTUIG (LEEU MK 1)}

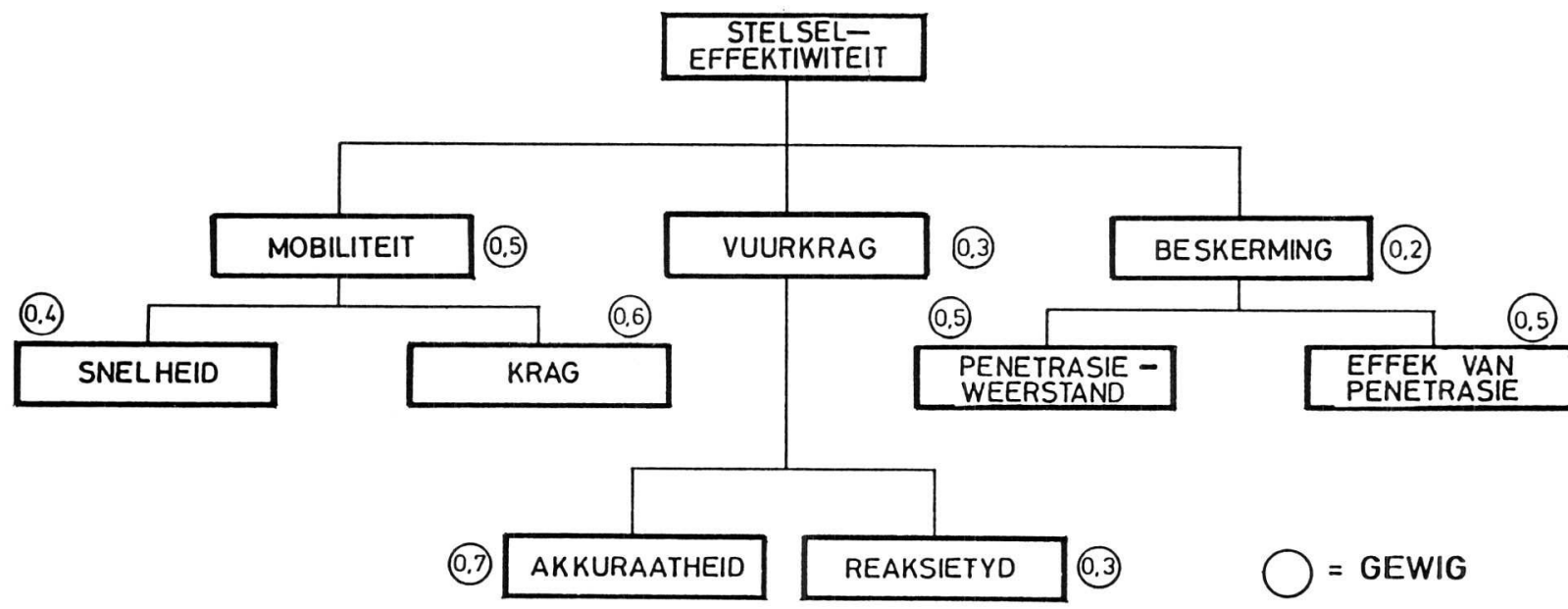


'n tenk wat nie behoorlik kan skiet nie, niks beteken nie, kan die stelseleffektiwiteitsyfer dus nie as betroubare maatstaf beskou word nie

\section{TEKORTKOMINGE VAN DIE HUIDIGE EVALUERINGSMODEL}

Soos deur die voorbeeld aangetoon, lê die eerste tekortkoming daarin dat swak eienskappe as gevolg van die sommeringsproses deur sterk eienskappe versluier word.

Die ontoepaslikheid van die optellingsbewerking is ' $n$ verdere tekortkoming. Dit kan gebeur dat voldoen moet word aan $\mathrm{k}$ uit $\mathrm{n}$ opsies, byvoorbeeld waar ' $n$ vereiste aan 'n valhelm gestel word om die draer se ken en/of ore te beskerm. Sou slegs een van die liggaamsdele beskerm word, word die vereiste geslaag. Hoe modelleer mens dit met optelling?

Die model laat laastens nie toe dat ' $n$ enkele effektiwiteitsyfer verkry word sonder om 'n kwalifikasie daaraan te koppel nie. So kan 'n minimum kwalifikasie aan 'n eienskap gekoppel word en die verlangde stelseleffektiwiteit steeds behaal word, sonder dat daar aan die minimum kwalifikasie voldoen word. Die resultaat moet dan gekwalifiseer word, byvoorbeeld 'n effektiwiteitsyfer van $\mathrm{x}$ is behaal, maar eienskap a is nie aan voldoen nie.

\section{DIE VERALGEMEENDE GEMIDDELDE MODEL}

$\mathrm{Na}$ aanleiding van bogenoemde tekortkominge is ' $n$ meerbewerkingsmodel - die veralgemeende gemiddelde - ontwikkel (Wagner, 1989, p9). Hierdie model gebruik optelling, vermenigvuldiging, mininum/maksimum en $k$ uit $n$ beslissings om ' $n$ meer sinvolle resultaat vanuit ' $n$ hiërargiese stelsel te verkry. Die begrip van 'n inkrementele gemiddelde het intussen bygekom maar word nie hier behandel nie.

\subsection{Toepassing van die veralgemeende gemiddelde}

Ten einde hierdie model toe te pas word die volgende stappe gevolg:

(a) Stel 'n hiërargiese boom op soos voorheen en stel dit grafies voor.

(b) Bepaal die onderlinge verhouding in terme van die reeds genoemde bewerkings tus- sen nodes op dieselfde vlak en wysig die grafiese voorstelling dienooreenkomstig.

(c) Bepaal gewigte per vlak.

(d) Definieer transformasies wat meetbare prestasies na breuke omskakel en voer die bewerking per faktor en per vlak uit.

\subsection{Die Bewerkings}

Die volgende bewerkings word in die hiërargiese stelsel gebruik en die beslissing ten opsigte van watter bewerking gebruik moet word, word gedoen aan die hand van onderstaande toetse. Deur Tabel 2 te gebruik, word die toetse stelselmatig uitgevoer en bepaal watter bewerking van toepassing is.

\subsubsection{Optelling}

(i) Toets 1 Dra al die faktore by tot die gemiddelde?

(ii) Toets 2 Word 'n faktor wat goed presteer toegelaat om op te maak vir 'n swak faktor?

\section{OF}

Tree die faktore plaasvervangend tot mekaar op? Met ander woorde kan een faktor wat glad nie presteer nie, vervang word deur 'n ander?

\section{OF}

Is die faktore onderling uitsluitend? (Spiegel, 1972, p. 100) Maw is daar 'n faktor wat die voorkoms van 'n ander faktor, of alle ander faktore, verhoed?

EN (indien enige van bg geld)

Is geen Boolese veranderlikes ( 0 of

1) betrokke nie?

\subsubsection{Vermenigvuldiging}

(i) Toets 3 Word 'n faktor wat goed presteer, toegelaat om beperk op te maak vir 'n swak presterende faktor?

\section{OF}

Is die faktor nie-plaasvervangend? Plaasvervanging vind plaas as een faktor deur ' $n$ ander faktor vervang word.

\section{OF}

Is daar Boolese veranderlikes ( 0 of 1) betrokke? 


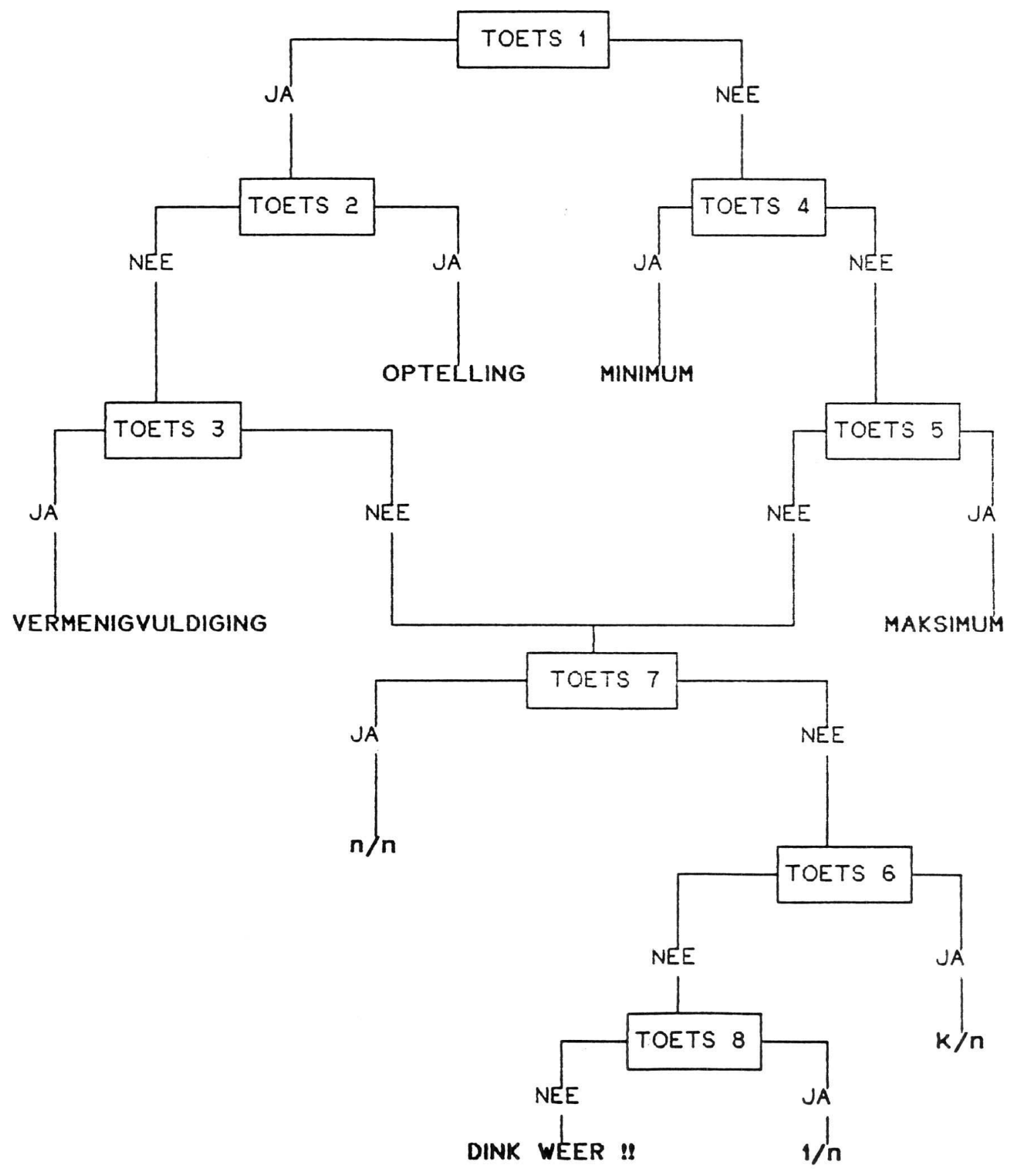

\subsubsection{Minimum}

(i) Toets 4 Dra net die swakste prestasie by tot die volgende bewerking?

\section{OF}

Kan die ander faktore geensins opmaak vir die swakste prestasie uit die versameling faktore nie?

\subsubsection{Maksimum}

(i) Toets 5 Dra die beste prestasie alleen by tot die volgende bewerking?

$\mathrm{OF}$

Kan die swak vertoning van die ander faktore glad nie die hoë prestasie van die beste faktor benadeel nie? 


\subsubsection{K uit $n$}

(i) Toets 6 Voldoen minstens $\mathrm{k}$ uit $\mathrm{n}$ faktore aan die vereiste? Die volgende geld:

$F_{i}=1, x>=k$

$F_{i}=0, x<k$, met $F_{i}=$ die waarde van die faktor $\mathrm{i}$ en $\mathrm{x}=$

suksesvolle waarnemings.

Dit is dus duidelik dat hier van 'n suiwer slaag/ druip toetsing gepraat word en die bewerking is Boolese van aard.

Verskeie variasies van hierdie bewerking bestaan, nl:
(a) n uit $n$
(b) I uit $n$
(c) I uit I

\subsubsection{1 n uit $n$}

(i) Toets 7 Voldoen al $\mathrm{n}$ uit $\mathrm{n}$ faktore aan die vereiste? Die volgende geld:

$$
\begin{aligned}
& F_{i}=1, x=n \\
& F_{i}=0, x<n \text {, met } F_{i}=\text { die waarde } \\
& \text { van die faktor } i \text { en } x= \\
& \text { suksesvolle waarnemings. }
\end{aligned}
$$

Hierdie bewerking het dieselfde funksie as die Boolese EN en word gebruik waar alle faktore/ vereistes in 'n versameling nie-onderhandelbaar is en gevolglik moet slaag.

\subsubsection{I uit $n$}

(i) Toets 8 Voldoen minstens 1 uit $\mathrm{n}$ faktore aan die vereiste? Die volgende geld:

$F_{i}=1, x>=1$

$F_{i}=0, x=0$, met $F_{i}=$ die waarde van die faktor $\mathrm{i}$ en $\mathrm{x}=$

suksesvolle waarnemings.

Die Boolese OF word deur hierdie bewerking voorgestel en laat die stelsel toe om te slaag as minstens 1 uit $\mathrm{n}$ saamgegroepeerde faktore aan die vereistes voldoen.

\subsubsection{1 uit 1}

As spesiale geval van toets 7 , is nie-onderhandelbaarheid die toets vir die toepassing van die 1 uit 1 bewerking, waar die enkele vereiste nie in 'n versameling saamgegroepeer kan word nie.

\subsection{Voorstellings van die model}

Die model kan op 2 maniere voorgestel word, nl:

(i) Grafies

(ii) Algebraïes

Hierdie voorstellings dien as hulpmiddel vir die bepaling van die resultaat van die evaluasie, sowel as 'n eenvoudige voorstelling van wat 'n ingewikkelde stelsel kan wees.

\section{Grafiese Voorstellings}

Tabel 3 dui grafiese voorstellings van elke bewerking in gebruik in hierdie model aan.

\subsubsection{Algebraïese Voorstelling}

Ten einde die eindresultaat van 'n hiërargiese stelsel, waarop hierdie model toegepas is, te kan bereken, moet dit algebraïes voorgestel kan word. Vir hierdie doel word normale wiskundige simbole en konvensies gebruik, soos aangedui in tabel 4.

\section{TABEL 4. ALGEBRAÏESE VOORSTELLING VAN BEWERKINGS}

\section{Bewerking}

1. Optelling van $F_{1}$ tot $F_{5}$

2. Vermenigvuldiging van $F_{6}$ tot $F_{10}$

3. Minimum van $F_{11}$ en $F_{12}$

4. Maksimum van $F_{14}$ en $F_{16}=\operatorname{maks}\left[F_{14}, F_{15}\right]$ $\mathrm{F}_{15}$

5. 1 uit 2 beslissing vir $F_{19}=1 /\left[F_{17}, F_{18}\right]$ $\mathrm{F}_{19}$

\section{VOORBEELDE}

Om die toepassing van die model te illustreer, word twee voorbeelde, naamlik die reeds bekende Leeu MK 1 en 'n dienspistool vir ' $n$ veiligheidsmaatskappy, bespreek.

\subsection{Leeu MK 1}

Al die faktore van die beginnodes (Diagram 1) dra by tot die gemiddelde (toets 1), 'n faktor wat goed presteer word toegelaat om beperk op te maak vir 'n swak presterende faktore en faktore 
TABEL 3. GRAFIESE VOORSTELLING VAN BEWERKINGS

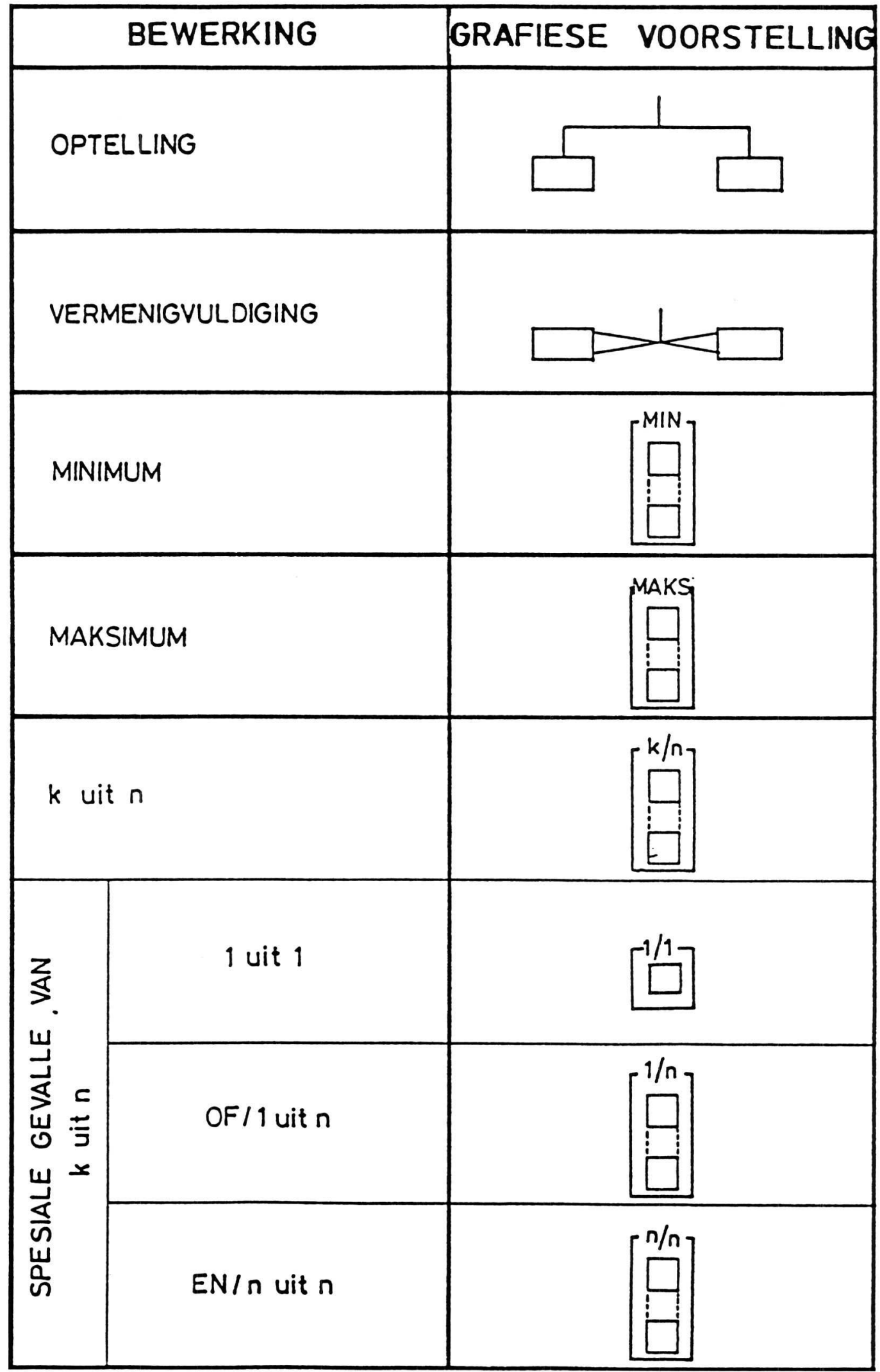

is nie-plaasvervangend (toets 3 ), vermenigvuldiging geld dus hier. Snelheid kan nie krag ver- vang nie en akkuraatheid nie reaksietyd nie, gevolglik geld vermenigvuldiging ook hier. Aan- 
gesien 'n goeie prestasie ten opsigte van die effek na penetrasie as plaasvervanger vir 'n swak penetrasie weerstand kan optree en omgekeerd (toets 2), geld optelling in hierdie geval. Die nuwe hiërargiese boom word voorgestel in Diagram 2, terwyl tabel 5 die nuwe bewerkinge voorstel. Let op die verskil in stelseleffektiwiteit tussen die huidige model en die veralgemeende gemiddelde model.

\section{TABEL 5. BEREKENINGE NA AANLEIDING VAN DIAGRAM 2}

$\begin{array}{lccc}\begin{array}{l}\text { Meetbare } \\ \text { eienskap }\end{array} & \begin{array}{c}\text { Breuk be- } \\ \text { haal }(P)\end{array} & \begin{array}{c}\text { Gewig }(G) \\ \text { Bereke- } \\ \text { ning }\end{array} \\ \begin{array}{l}\text { Snelheid } \\ \text { Krag }\end{array} & 0,9 & 0,4 & \mathrm{p}^{\mathrm{G}}=0,9587 \\ \begin{array}{l}\text { Akkuraatheid } \\ \text { Reaksietyd }\end{array} & 0,9 & 0,6 & \mathrm{P}^{\mathrm{G}}=0,9387 \\ \begin{array}{c}\text { Penetrasie; } \\ \text { weerstand }\end{array} & 0,1 & 0,7 & \mathrm{P}^{\mathrm{G}}=0,1995 \\ \begin{array}{c}\text { Effek na } \\ \text { penetrasie }\end{array} & 0,7 & 0,3 & \mathrm{P}^{\mathrm{G}}=0,5012 \\ & 0,6 & 0,5 & \mathrm{P} \times \mathrm{G}=0,35 \\ & & & \end{array}$

bruik. Die stappe waarin die projek aangepak sal word, is as volg:

(i) Bepaal die vereistes vir die mees geskikte pistool en stel dit grafies voor.

(ii) Pas die model toe, en wel in die volgende deelstappe:

(a) Bepaal die verhouding van elke eienskap/vereiste mbt die bewerkings ten opsigte van mekaar en stel die model grafies voor.

(b) Bepaal gewigte op die vlakke waar van toepassing.

(c) Stel grafieke op of bepaal algebraïese formules om resultate te omskep na prestasiewaardes in die vorm van breuke.

(iii) Evalueer elke eienskap/vereiste van voorafgeïdentifiseerde kandidate, bepaal die stelseleffektiwiteit van elk en kies die beste.

\subsubsection{Vereistes}

(i) Prys. Die eenheidsprys van die wapen moet minder as R3000 wees, maar verkieslik R400.

(ii) Funksionele vereistes

(a) Veiligheid. Nadat die wapen oorgehaal is, moet of die hamer self sak as die

\section{DIAGRAM 2. VERALGEMEENDE GEMIDDELDE TOEGEPAS OP DIE LEEU MK 1}

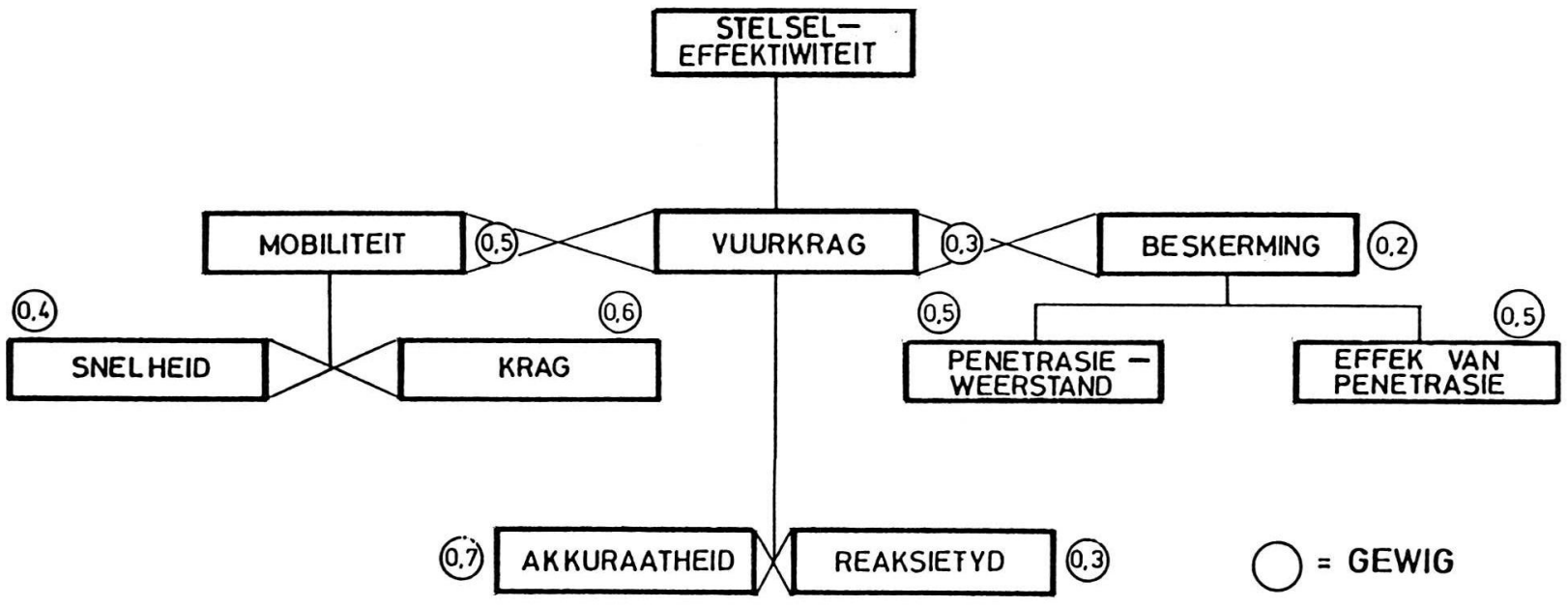

\subsection{Evaluasie van 'n pistool}

Gestel 'n pistool moet aangekoop word vir gebruik deur veiligheidswagte. Ten einde die beste pistool vir die doel aan te koop, word besluit om die veralgemeende gemiddelde model te ge- veiligheidsknip gekoppel word, of die wapen moet in die sg oorgehaal en gesluit (Eng cocked and locked) stand gedra kan word.

(b) Magasyn. Die magasyn moet verkieslik 
15 patrone, maar nie minder as sewe, dra.

(c) Visiere. Die visiere moet gerond wees en beide moet verstelbaar wees.

(iii) Vuurkrag

(a) Kaliber. Die kaliber moet $9 \mathrm{~mm}$ parabellum wees ter wille van die relatiewe stopkrag en koste van die ammunisie.

(b) Akkuraatheid. Vanuit 'n vaste montasie moet die akkuraatheid as volg wees:

(1) $25 \mathrm{~m}$. Tien skote binne ' $\mathrm{n}$ sirkel met 'n deursnit van $5 \mathrm{~cm}$.

(2) $50 \mathrm{~m}$. Tien skote binne 'n sirkel met 'n deursnit van $12 \mathrm{~cm}$.

(3) $100 \mathrm{~m}$. Tien skote binne 'n sirkel met ' $n$ deursnit van $30 \mathrm{~cm}$.

(iv) Ergonomika

(a) Greep. Die greep moet gemaklik in 95\% (minimum 60\%) van die gebruikers se hande pas.

(b) Plasing van Knippe. Beide die veiligheidsknip en magasynknip moet so geplaas word dat dit met een hand gekoppel en ontkoppel kan word.

(c) Gewig. Die pistool moet minder as 600 g weeg.

(d) Dra-eienskap. Die pistool moet gemaklik en onopsigtelik of onder die arm of aan ' $n$ lyfband gedra kan word of beide. (v) Betroubaarheid. Gemicidelde aantal skote tussen storings: 500 of meer.

Die vereistes is vervolgens grafies in ' $n$ hiërargiese boom voorgestel (sien diagram 3 ).

\subsubsection{Toepassing van die model}

Die bewerkings tussen die vereistes word vervolgens bepaal en gewigte toegeken (sien diagram 4). Let op die gewig van 1 wat aan die vereistes "hamer sak" en "cocked and locked" toegeken word vanweë die feit dat hulle onderling uitsluitend is. Hierna is grafieke geteken wat prestasiewaardes aan resultate toeken (sien diagram 5).

$\mathrm{Na}$ aanleiding van bogenoemde model is etlike pistole geëvalueer waarvan die resultate van een in tabel 6 gegee word

Die berekeninge na aanleiding van tabel 5 is as volg:

$$
\begin{aligned}
& F_{10}=\min (0,71 ; 0,75 ; 0,80)=0,71 \\
& F_{7}=F_{9}=F_{11}=F_{14}=1 \\
& F_{12}=1 \times 1+1 \times 0=1 \\
& F_{1}=0,86^{0,50} \cdot 1^{0,20} 0,75^{0,20} \cdot 1^{0,10}= \\
& F_{2}=0,88 \\
& F_{3}=1^{0,5}, 0,11^{0,6} \cdot 1^{0,4}=0,81 \\
&
\end{aligned}
$$

DIAGRAM 3. HIËRARGIESE BOOM VIR DIE EVALUERING VAN 'N PISTOOL (VERALGEMEENDE GEMIDDELDE MODEL NOG NIE TOEGEPAS NIE)

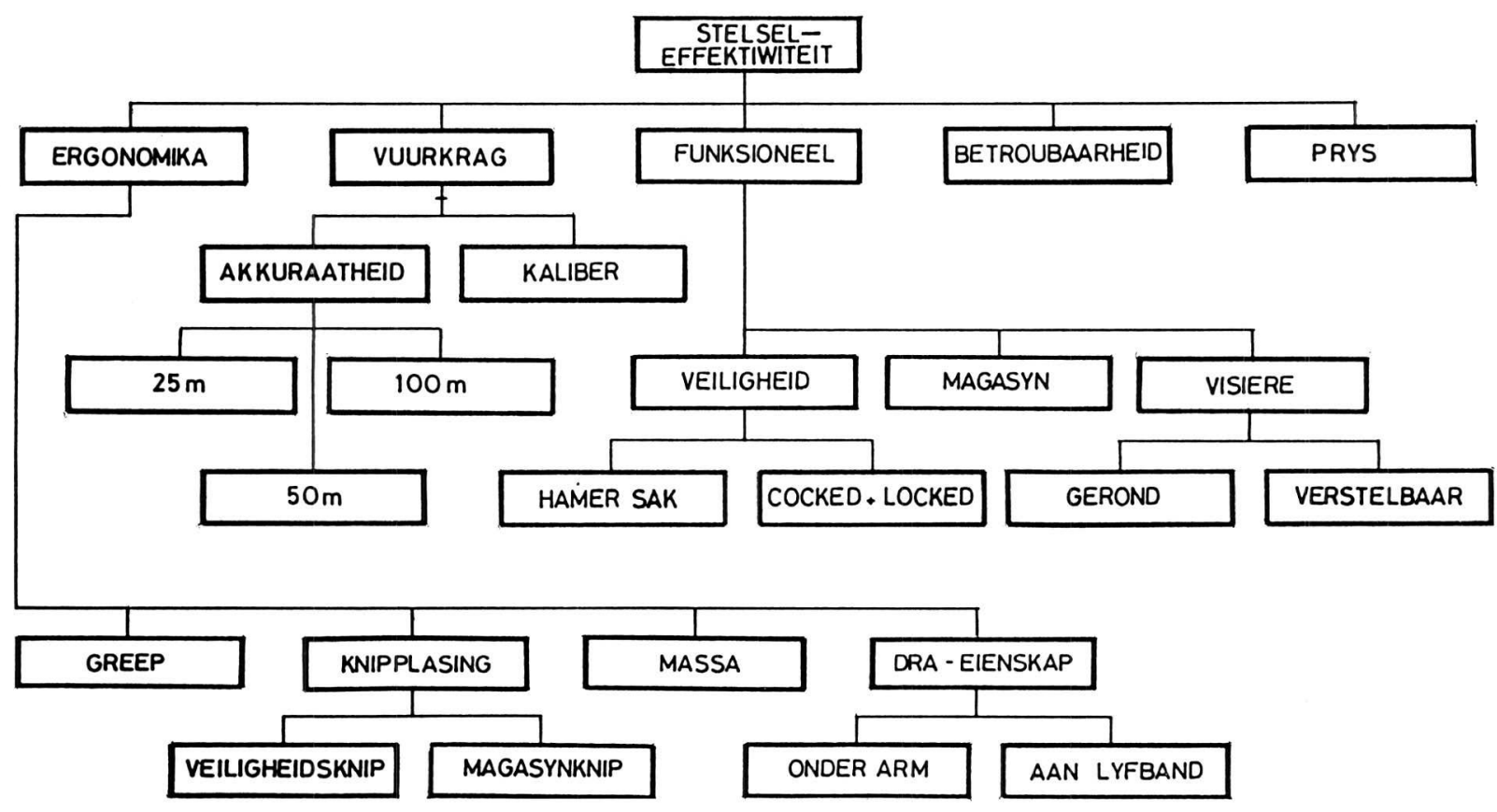




\section{DIAGRAM 4. HIËRARGIESE BOOM VIR DIE EVALUERING VAN 'N PISTOOL (VERALGEMEENDE GEMIDDELDE MODEL TOEGEPAS)}

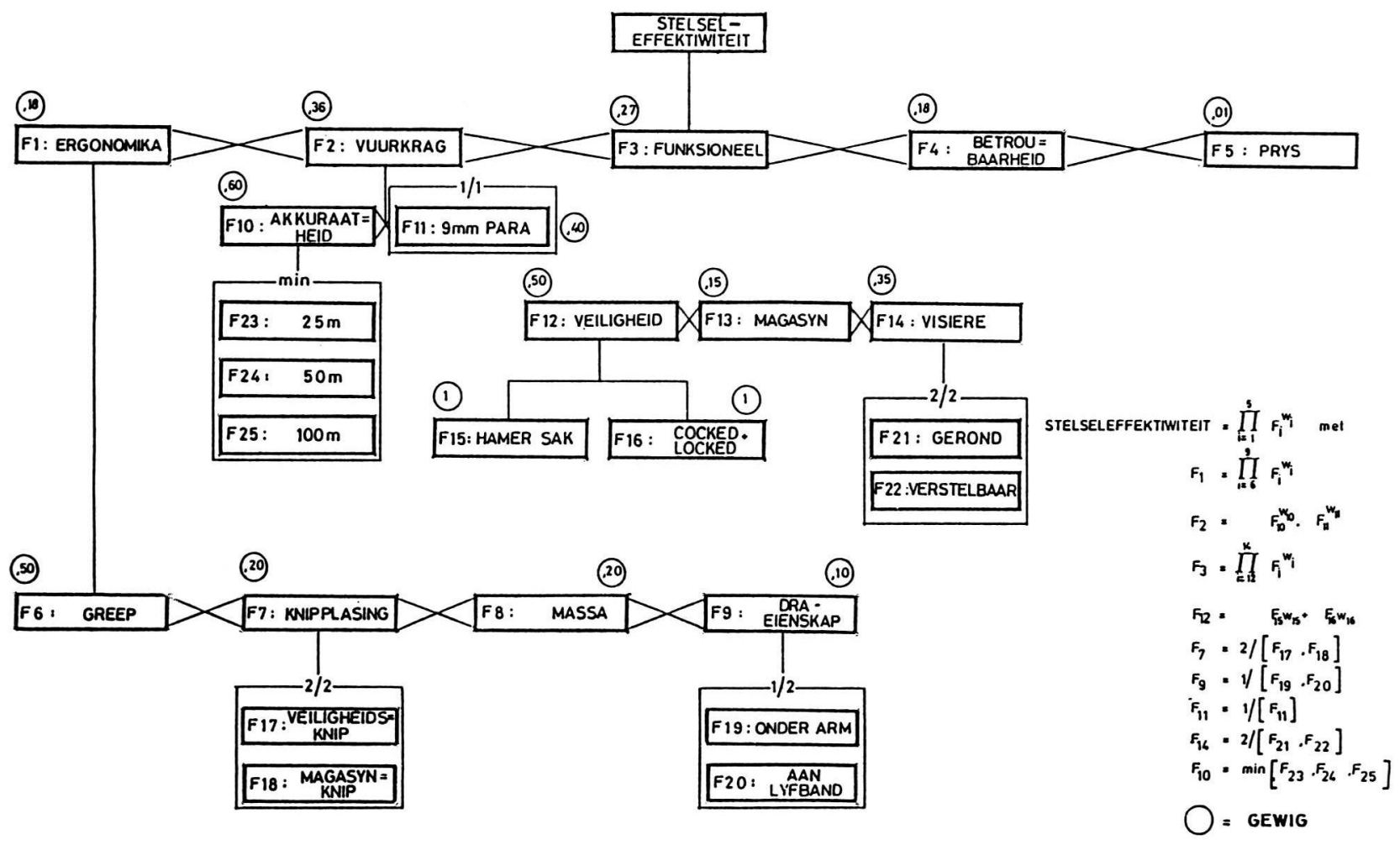

TABEL 6. BEREKENINGE

\begin{tabular}{|c|c|c|}
\hline Vereiste & Resultaat & Breuk \\
\hline Greep & $90 \%$ & 0,86 \\
\hline Knippassing & $\begin{array}{l}\text { Beide korrek } \\
\text { geplaas }\end{array}$ & 1 \\
\hline Massa & $700 \mathrm{~g}$ & 0,75 \\
\hline Dra-eienskap & $\begin{array}{l}\text { Dra goed } \\
\text { onder arm }\end{array}$ & 1 \\
\hline \multicolumn{3}{|l|}{$\begin{array}{l}\text { Akkuraat- } \\
\text { heid: }\end{array}$} \\
\hline $25 \mathrm{~m}$ & $7 \mathrm{~cm}$ & 0,71 \\
\hline $50 \mathrm{~m}$ & $15 \mathrm{~cm}$ & 0,75 \\
\hline $100 \mathrm{~m}$ & $32 \mathrm{~cm}$ & 0,80 \\
\hline $\begin{array}{c}\text { Kaliber } 9 \mathrm{~mm} \\
\text { parabellum }\end{array}$ & & 1 \\
\hline Hamer sak & & 1 \\
\hline Magasyn & $\begin{array}{l}\text { Neem } 8 \text { pa- } \\
\text { trone }\end{array}$ & 0,12 \\
\hline Visiere & $\begin{array}{l}\text { Gerond en } \\
\text { verstelbaar }\end{array}$ & 1 \\
\hline $\begin{array}{l}\text { Betroubaar- } \\
\text { heid }\end{array}$ & 400 skote & 0,75 \\
\hline Prys & $\mathrm{R} 2200$ & 0,31 \\
\hline
\end{tabular}

$$
\begin{aligned}
\mathrm{SE}= & 0,88^{0,18} 0,81^{0,36} \\
& 0,73^{0,27} 0,75^{0,18} \cdot 0,31^{0,01} \\
= & 0,78
\end{aligned}
$$

\section{VOORDELE VAN DIE METODE}

Uit bogenoemde voorbeelde spreek dit vanself dat die veralgemeende gemiddelde model lei tot sinvolle resultate wanneer uitrusting getoets word, effektiwiteit bepaal word of verskeie items vergelyk word. Die voordele, naamlik:

(a) die daarstelling van 'n enkelsyferwaarde, sonder die byvoeging van 'n verdere kwalifikasie;

(b) die toepaslikheid van bewerkinge;

(c) en die duidelike vertoon van swak eienskappe

maak hierdie model uiters geskik vir die evaluering van alle uitrusting binne die militêre omgewing.

\section{VERDERE TOEPASSINGS}

Dit is duidelik dat hierdie metode nie net beperk is tot die evaluering van uitrusting nie, maar aangewend kan word om enige stelsel of besluitnemingsproses te evalueer. Voorbeelde sluit in die evaluering van die gevegsgereedheid van 'n eenheid. Dit word tans gedoen deur merkstate te gebruik waarna 'n verslag, gebaseer op die vertolking van die resultaat, geskryf word. Deur 
DIAGRAM 5. GRAFIEKE WAT RESULTATE OMSKAKEL NA PRESTASIEWAARDES

GREEP

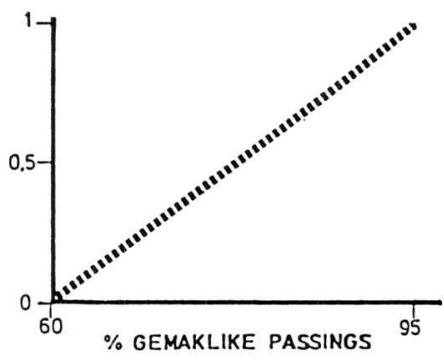
MASSA

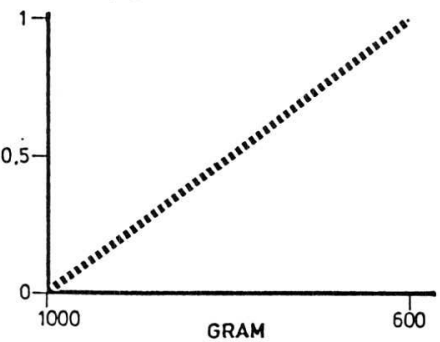

AKKURAATHEID

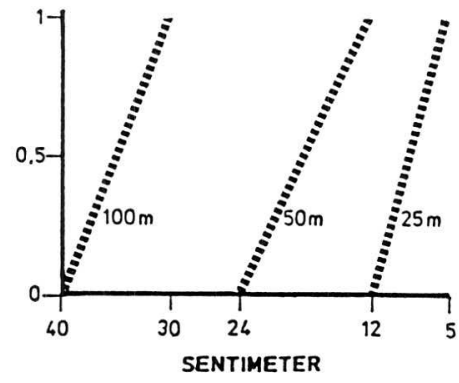

'n hiërargiese boom vir elke kritiese prestasiearea (KPA) op te stel en hulle saam te voeg in 'n groter hiërargiese boom wat gevegsgereedheid voorstel, kan die metodiek van toepassing gemaak word op KPA's en hulle saamgevoegde resultaat, gevegsgereedheid.

Dit moet egter nie verwag word dat die veralgemeende gemiddelde model op alle besluitnemingsprobleme toegepas kan word nie. In gevalle waar beperkings of voorwaardes op die probleem geplaas word, is dit byvoorbeeld beter om liniêre programmering of ander toepaslike optimeringstegnieke te gebruik. Hierdie probleemoplossingsmetode kan met groot welslae aangewend word om onder andere die volgende probleme op te los:

(a) Liggingsprobleme waar strategiese installasies of eenhede geplaas moet word onder beperkings soos die afstand vanaf sleutelpunte, beskikbare infrastruktuur, ens met die doel om maksimum operasionele effektiwiteit te verkry

(b) Begrotingsprobleme waardeur fondse toegeken word met ' $n$ beperking op die totale
GEMIDDELDE SKOTE TUSSEN STORINGS.

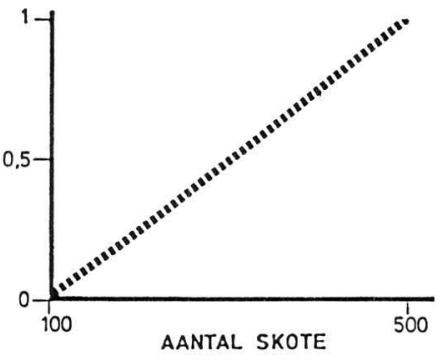

PRYS

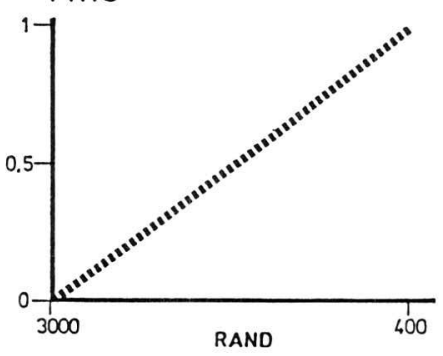

PATRONE IN ' $n$ MAGASYN

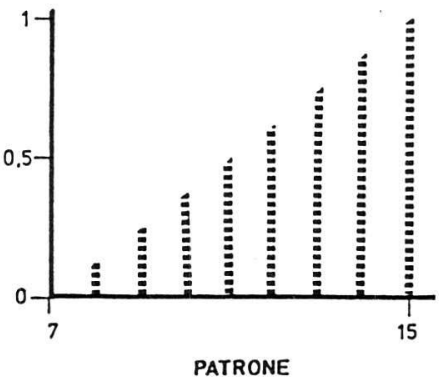

bedrag beskikbaar en met die doel om operasionele doeltreffendheid te maksimeer.

(c) Vervoerprobleme wat die vervoer en opberging van kommoditeite teen minimum koste behels.

Die verdere bespreking van hierdie metodes val buite die bestek van hierdie geskrif, maar enige versoeke om hulp met die toepassing van enige van bg tegnieke sal deur die outeurs verwelkom word.

*Kmdt W.J. Wagner, SAPK, B.Mil (Stell) M.Sc (Unisa) is verbonde aan Leër HK.

Prof J.S. Wolvaardt, Sci Nat, M.Sc(Pret), M.Sc, Ph.D (Unisa) is verbonde aan die Departement Kwantitatiewe Bestuur, Unisa.

\section{LITERATUURLYS}

1. AANGEHAALDE BRONNE

Wagner, W.J. 1989. 'n Nuwe Model vir Uitrustingsevaluering. Pretoria, MSc verhandeling: Universiteit van Suid-Afrika. $45 \mathrm{p}$.

Spiegel, M.R. 1972. Schaum Outline Series: Theory and Problems of Statistics. London: McGraw-Hill. 359 p.

2. GERAADPLEEGDE BRONNE

Arnold, D. 1979. Shoot a Handgun. Johannesburg: Ernest Stanton, 144 p. Hilmes, R. 1987. Main Battle Tanks, Developments in Design since 1945. 0xford: Brassey's Defence Publishers. $130 \mathrm{p}$. 